\title{
Design Goals and Challenges for a Photovoltaic-Powered Electrochromic Window Covering
}

D. K. Benson, H. M. Branz

Prepared for the

First International Meeting on

Electrochromism

October 19-21, 1994

Murano-Venice, Italy

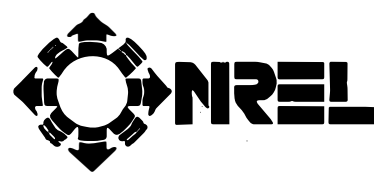

National Renewable Energy Laboratory 1617 Cole Boulevard Golden, Colorado 80401-3393

A national laboratory of the U.S. Department of Energy Managed by Midwest Research Institute for the U.S. Department of Energy under contract No. DE-AC36-83CH10093

Prepared under Task No. ER480101

December 1994 


\section{NOTICE}

This report was prepared as an account of work sponsored by an agency of the United States government. Neither the United States government nor any agency thereof, nor any of their employees, makes any warranty, express or implied, or assumes any legal liability or responsibility for the accuracy, completeness, or usefulness of any information, apparatus, product, or process disclosed, or represents that its use would not infringe privately owned rights. Reference herein to any specific commercial product, process, or service by trade name, trademark, manufacturer, or otherwise does not necessarily constitute or imply its endorsement, recommendation, or favoring by the United States government or any agency thereof. The views and opinions of authors expressed herein do not necessarily state or reflect those of the United States government or any agency thereof.

Available to DOE and DOE contractors from:

Office of Scientific and Technical Information (OSTI)

P.O. Box 62

Oak Ridge, TN 37831

Prices available by calling (615) 576-8401

Available to the public from:

National Technical Information Service (NTIS)

U.S. Department of Commerce

5285 Port Royal Road

Springfield, VA 22161

(703) 487-4650

\footnotetext{
$=\quad$ Printed on paper containing at least $50 \%$ wastepaper and $10 \%$ postconsumer waste
} 
Submitted for inclusion in the Proceedings of the First International Meeting on Electrochromism, Murano-Venice, Italy, October 19-21, 1994, to be published in Solar Energy Materials and Solar Cells, 1995.

\title{
DESIGN GOALS AND CHALLENGES FOR A PHOTOVOLTAIC-POWERED ELECTROCHROMIC WINDOW COVERING
}

\author{
David K. Benson and Howard M. Branz \\ Basic Sciences Division, National Renewable Energy Laboratory \\ Golden, Colorado, USA
}

An estimated $1.0 \%-1.5 \%$ of the total cooling energy need in U.S. buildings, and $10 \%-30 \%$ of the peak electric utility power demand, is caused by unwanted solar heat-gain through windows. A large fraction of the approximately two billion square meters of building windows in the United States could benefit from the use of some solar gain control strategy. If a cost-effective, retrofit, electrochromic (EC) window covering were available, this energy savings potential could be realized in a relatively short time.

A "glue on," retrofit EC window treatment, similar to conventional static solar-gain control .films, could accelerate the application of this new technology in buildings. However, the costs of electrical wiring for each retrofitted window could dominate the economics of the retrofit decision and slow market acceptance of EC windows. By incorporating a photovoltaic (PV) power source into the EC window retrofit, this wiring cost could be reduced or eliminated, and the installation of the EC window treatment could be greatly simplified.

In this paper, we suggest the use of an integrated, photovoltaic-powered electrochromic (PVEC) window treatment that can be applied to an existing window in much the same way that conventional, static, solar-gain control films are now applied. This concept is the subject of a new three-year research and development (R\&D) project at our laboratory. We present our design concepts and rationale and identify some of the technical challenges involved.

\section{PV-EC window treatments}

The PV-EC window treatment will consist of multi-layer, thin-film devices applied to a flexible polymer sheet. This sheet will be glued to the indoor side of the existing window. The PV and EC components may be applied in either a side-by-side or tandem arrangement. The side-by-side design would orient the thin-film PV power source around the perimeter of the window area and the EC film in the central portion of the window (Fig. 1A). The tandem design would apply both the PV and EC coatings over the entire area of the window so that the sunlight would pass through both components (Fig. 1B).

The operation of the PV-EC window could be controlled from a central location, such as an automatic building energy management system, locally by the building occupant, or perhaps by an integral control box attached to each window. In many applications, occupant override controls will be necessary, as will a secondary storage battery to provide power at night and at other times when direct PV power is inadequate. A daylighting control system would 
include a sensor to detect the lighting level in the adjacent workspace and a means for the occupants to adjust the control setting of the PV-EC window to maintain the desired lighting level (so long as sufficient daylight were available). The automatic control of lighting level would operate best and provide the maximum conservation of electrical power if the PV-EC window were used in conjunction with self-dimming, energy-efficient fluorescent lighting in the workspace. These self-dimming lights would operate automatically as needed to provide the set level of lighting whenever the daylight through the window became inadequate.

A control system designed to maximize energy conservation would also include sensors to detect both indoor and outdoor temperatures so that the window control strategy could be different under weather conditions requiring building heating versus building cooling and so that solar overheating of the adjacent workspace could be avoided. The addition of an occupancy sensor in the window controls would allow the window to operate automatically as a solar heat-gain modulator whenever daylighting was not needed by an occupant. An energy-conserving control strategy for "smart" windows using all of these concepts has been described by Bartovics [1]. A block diagram of the control elements is shown in Fig. 2.

\section{Applicability of PV-EC for retrofit}

The EC window coatings are primarily solar energy absorbers. They are effective in blocking solar heat-gain to the extent that the solar heat absorbed by the EC is preferentially rejected outside the building rather than conducted into it. Consequently, the best location for an EC would be on the number 1 surface (numbering from outdoors to indoors) if it were not for weather-related durability concerns. The best location, taking durability into account, is the number 2 surface of a sealed, insulating glass window unit (SIGU), where the EC can be protected and where it obviously has a better heat conduction path to the outside than to the inside of the building.

How well might an EC treatment reject solar heat-gain if it were applied to the indoor surface of a window (the number 2 surface of a single glazing or the number 4 surface of a SIGU)? Estimates of the heat-gain through EC windows with the EC on different surfaces were made using a thermal model for window performance [2]. Standard summer conditions were assumed for a typical, large (1.2 m wide x $1.8 \mathrm{~m}$ high), vertical, south-facing window (3). Conditions modeled were as follows: outside temperature $=31.7 \circ \mathrm{C}$; inside temperature $=$ $23.9 \circ \mathrm{C}$; solar irradiance $=783 \mathrm{~W} / \mathrm{m}^{2}$; and wind speed $=3.3 \mathrm{~m} / \mathrm{s}$. The window frame was assumed to be made of aluminum with the outside part of the frame thermally isolated from the inside part of the frame by a polymer coupling (a so-called "thermal break"). The EC was assumed to be constructed so as to have a reduced emittance $(0.2)$ on its exposed surface.

Figure 3 shows the estimated total heat gain through the windows as a function of their total solar transmission, assuming that the EC attenuates the solar irradiance by absorption. Three different curves are shown for three different cases. Curve $\mathrm{C}$ is the estimate for the optimum case with the EC on the number 2 surface in a SIGU. Curve A is the case of a retrofit EC on surface number 4 of the same SIGU. Curve B is the case of a retrofit EC on the number 2 surface of a single-glazed window. In the model, the total heat gain through the window was calculated as the product of the shading coefficient and the solar heat gain factor plus the 
product of the window conductance and the difference between indoor and outdoor temperatures [3]. In all of these cases, as shown in Fig. 3, the EC is predicted to be significantly useful in reducing solar heat gain whenever solar transmission is below $75 \%$.

Without the reduced emittance, the EC performance estimates are not nearly as favorable. Figure 4 shows a comparison of the predicted solar heat-gain through a double-glazed SIGU with EC on surface number 4 with and without reduced emittance. The reduced emittance surface is an important component in the design of the retrofit EC because a large fraction of the heat transfer into the building occurs by radiation from the solar-heated EC, and this radiative heat transfer is proportional to the EC emittance.

\section{Potential advantages}

There are several advantages of a retrofit EC window treatment and particular advantages of a retrofit PV-EC treatment. Obviously, a retrofit EC provides an opportunity to improve the thermal performance of a very large number of existing windows long before these windows would be replaced with new EC windows. Less obvious is the possibility that retrofit EC windows might more readily find market acceptance. This easier market acceptance could occur if the building industry is concerned about the unproven durability, reliability and lifetime of an EC window. A retrofit EC could be more easily removed or replaced if it should fail. Indeed, a retrofit EC may be acceptable to the building market if it is designed with a much shorter service lifetime than a new window; perhaps 5 to 10 years for a retrofit versus 15 to 35 years for a "permanent" EC window.

The PV-EC window retrofit may also reduce the installed cost of EC windows by reducing or eliminating the costs of electrical wiring and electrician labor.

\section{Proof of concept}

Table 1 lists some typical characteristics of EC coatings and thin-film, hydrogenated amorphous silicon (a-Si:H) PV cells and shows their general compatibility. The output voltage of an a-Si: $\mathrm{H}$, thin-film $\mathrm{PV}$ cell is less than $1 \mathrm{~V}$, and the voltage required to switch a conventional EC device is just over $1 \mathrm{~V}$. The typical PV current density output is compatible with the switching requirements of an EC device, as are the overall energy and power densities. A small area of PV cells provides sufficient electrical power to switch a large-area EC window slowly, as would be appropriate for an architectural window. In the side-by-side PV-EC design, the PV array can be interconnected to provide multiples of the individual cell voltages. In the tandem PV-EC design, the single-cell PV voltage can be increased to over $1.4 \mathrm{~V}$ by incorporating a dual-junction cell at some cost in window transparency.

It is a straight-forward experiment to connect a PV array to an EC device and produce switching with the power from incident sunlight, and we demonstrated this at NREL. It is not so easy to show that the power from a semi-transparent PV cell can switch an EC deposited onto the PV cell in a tandem arrangement. 
A simple EC design that could be deposited by sequential thermal evaporation was selected for testing in a laboratory proof-of-concept PV-EC device. This EC was the so-called Deb design shown on the left in Fig. 5. This EC requires about $1.4 \mathrm{~V}$ for coloration because it depends upon the ionization of water in the hydrated magnesium fluoride. This relatively high EC operating voltage dictates the use of a tandem PV cell, such as that shown on the right in Fig. 5.

A thin (1 micron) a-Si:H tandem PV device was available and was used as the substrate onto which the EC was deposited. The EC film layer thicknesses were selected to produce an EC device with an internal resistance of about 1000 ohms to allow the PV device to operate at its highest voltage (near open-circuit condition) during coloration. We found that a very thin layer of gold between the EC and PV devices provided the needed ohmic interconnect.

The overall transmittance of the PV-EC test device was only a few percent because of the semi-transparent gold interconnection layer and because wide-band-gap amorphous silicon alloys were not incorporated in this test device. This limited transmittance was sufficient to allow us to monitor the coloration of the EC layer with a helium-neon laser (633 nm wavelength). Figure 6 shows the test setup and a typical recording of the PV-powered EC relative transmittance switching under tungsten light illumination (approximately one sun equivalent). The PV open-circuit voltage under this illumination was 1.55-1.59 V. During coloration, the PV voltage imposed upon the EC layer was about $1.5 \mathrm{~V}$ and the coloration current was a maximum of $2.5 \mathrm{~mA}$, decreasing as the EC darkened.

\section{Technical challenges}

While the experiments show the laboratory feasibility of the PV-EC tandem design, they also show that many improvements will be necessary for a practical PV-EC tandem design. For a single PV cell to be used (rather than a more expensive and more opaque tandem stack), the EC layer will need to operate at a voltage of less than $1 \mathrm{~V}$. This lower-voltage operation may be accomplished with a properly configured lithium-ion insertion EC.

The optical band gap of the PV cell will have to be extended to above $2.0 \mathrm{eV}$ to make it sufficiently transparent and not too colorful. Figure 7 shows the theoretical limiting current density as a function of the abrupt optical band gap, along with some recent experimental measurements of thin PV cells [4]. Single-junction a-Si:H PV cells have produced shortcircuit current densities $\left(\mathrm{J}_{\mathrm{sc}}\right)$ of $16 \mathrm{~mA} / \mathrm{cm}^{2}$ before light-soaking [5]. This result compares well with the theoretical limit of about $18 \mathrm{~mA} / \mathrm{cm}^{2}$. Alloying the silicon with carbon increases the band gap at the cost of increased defect density and reduced cell efficiency. Single-junction a-SiC:H PV cells with band gaps of $1.9 \mathrm{eV}$ have produced maximum powerpoint currents greater than $6 \mathrm{~mA} / \mathrm{cm}^{2}$ [6]. Note that less than $1 \mathrm{~mA} / \mathrm{cm}^{2}$ is required to operate the tandem design PV-EC window with reasonable switching times. A more transparent interconnection layer, such as a transparent conductive oxide, will have to replace the semitransparent gold layer used in the laboratory proof-of-concept experiments.

The complete stack of layers in the PV-EC tandem design may look something like the diagram shown in Fig. 8. A total of nine layers is required with a total deposited film 
thickness of about three microns. One of the two polymer films will be the deposition substrate, and the other will be a protective superstrate adhesively bonded to the completed PV-EC stack. An abrasion-resistant coating will be needed to protect the exposed polymer superstrate from the normal wear and tear of periodic window cleaning. As indicated previously, a low-emittance coating on the exposed surface of the polymer superstrate would increase the EC window thermal performance significantly. If such a low-emittance coating is used, then the anti-abrasion coating over it will have to be transparent in the thermal infrared wavelength range ( 7 to 14 microns) in order for the low-emittance coating to be effective.

Developing processes to deposit all of these layers on polymer substrates in a cost-effective manner is a major technical challenge.

\section{Conclusions}

A PV-EC retrofit window treatment for buildings may have advantages of wider applicability and lower installed costs. Estimates suggest that the retrofit EC would not perform as well in reducing unwanted solar heat-gains as would a new, permanent EC window. However, the retrofit EC is predicted to provide significant energy conservation benefits in addition to its primary functions of daylighting control and glare reduction.

The integral PV power source in the proposed retrofit is expected to reduce the installed cost of the EC window by reducing or eliminating wiring and electrician labor costs.

Because the retrofit PV-EC window treatment can be readily removed or replaced, it may reduce market concerns about unproven EC durability, reliability, and lifetime and may thereby accelerate market acceptance of EC windows.

Two different design options, a design with PV side-by-side with the EC and a design with the PV and EC stacked on top of one another, are being evaluated at NREL. We have showr both designs to be technically feasible, but many technical barriers must be overcome before the practical feasibility of these design concepts can be determined.

\section{Acknowledgements}

The authors gratefully acknowledge the assistance of colleagues J.-G. Zhang, C.E. Tracy, and E. Iwaniczko for their fabrication and testing of the PV-EC tandem proof-of-concept device. This work is sponsored by the U.S Department of Energy, Office of Advanced Energy Projects, under Contract No. DE-AC-36-83CH10093. 


\section{References}

1. W. A. Bartovics, "The Thermal Performance of Fixed and Variable Selective Transmitters in Commercial Architecture", $M$. S. Thesis, MIT, Cambridge, MA, USA, 1984 .

2. "Windows 3.1, Windows and Daylighting Group, Lawrence Berkeley Laboratory Report LBL-25686. 1988.

3. ASHRAE, Handbook of Fundamentals pp. 27.18-27.19, American Society of Heating, Refrigeration and Air-Conditioning Engineers, New York, 1993.

4. M. Wolf, Proc. IRE, vol. 48, pp 1246-1263, July, 1960.

5. Y.-M. Li, Proc. MRS Spring Meeting, April 1993.

6. S. Guha, USSC Annual Subcontractor Report, 1 Jan. 1992- 28

Feb. 1993, NREL Report TP-411-5654, July 1993 
Table 1. PV and EC Compatibilities

\begin{tabular}{lcc}
\hline General characteristics & $\begin{array}{c}\text { PV } \\
\text { (a-Si:H, 5\% efficient) }\end{array}$ & $\begin{array}{c}\mathrm{EC} \\
\left(\mathrm{Li}^{+} \text {ion based }\right)\end{array}$ \\
\hline Voltage (V) & 0.85 & 0.80 \\
Current density $\left(\mathrm{A} / \mathrm{m}^{2}\right)$ & $35^{+}$ & $10^{*}$ \\
\hline $\begin{array}{l}\text { PV Requirements for } \\
\text { switching one meter }{ }^{2} \mathrm{EC}^{+}\end{array}$ & $\begin{array}{c}\text { PV area x conversion } \\
\text { efficiency }\left(\mathrm{m}^{2}\right)\end{array}$ & $\begin{array}{c}\text { Switching time } \\
(\mathrm{s})\end{array}$ \\
\hline & 0.005 & 80 \\
& 0.05 & 8 \\
\hline
\end{tabular}

EC switching, $1 \mathrm{~m}^{2}$ area, 50\%-10\% Tsolar in $<60$ seconds

${ }^{+}$Assume $600 \mathrm{~W} / \mathrm{m}^{2}$ solar irradiance 
Figure Captions

1. Schematic diagram of two PV-EC window design concepts: Side-by-side deployment of PV and EC components (A, left), and tandem deployment with PV and EC components covering entire window area ( $B$, right).

2. Block diagram of PV-EC control elements. Arrows indicate information flow.

3. Estimated total heat transfer through large windows with PV-EC treatments on different surfaces. Arrows indicate incident sunlight.

4. Estimated total heat transfer through a PV-EC window with and without a low-emittance coating on the exposed surface of the EC. The PV-EC treatment is on the number 4 surface of a SIGU.

5. Schematic cross-section of an experimental, tandem, proof-of-concept PV-EC device.

6. Test setup schematic and optical switching results for a tandem, proof-of-concept PV-EC device.

7. Theoretical limiting PV current under solar illumination with two examples of recent thinfilm PV cell measurements.

8. Cross-sectional diagram of a possible tandem PV-EC device. 


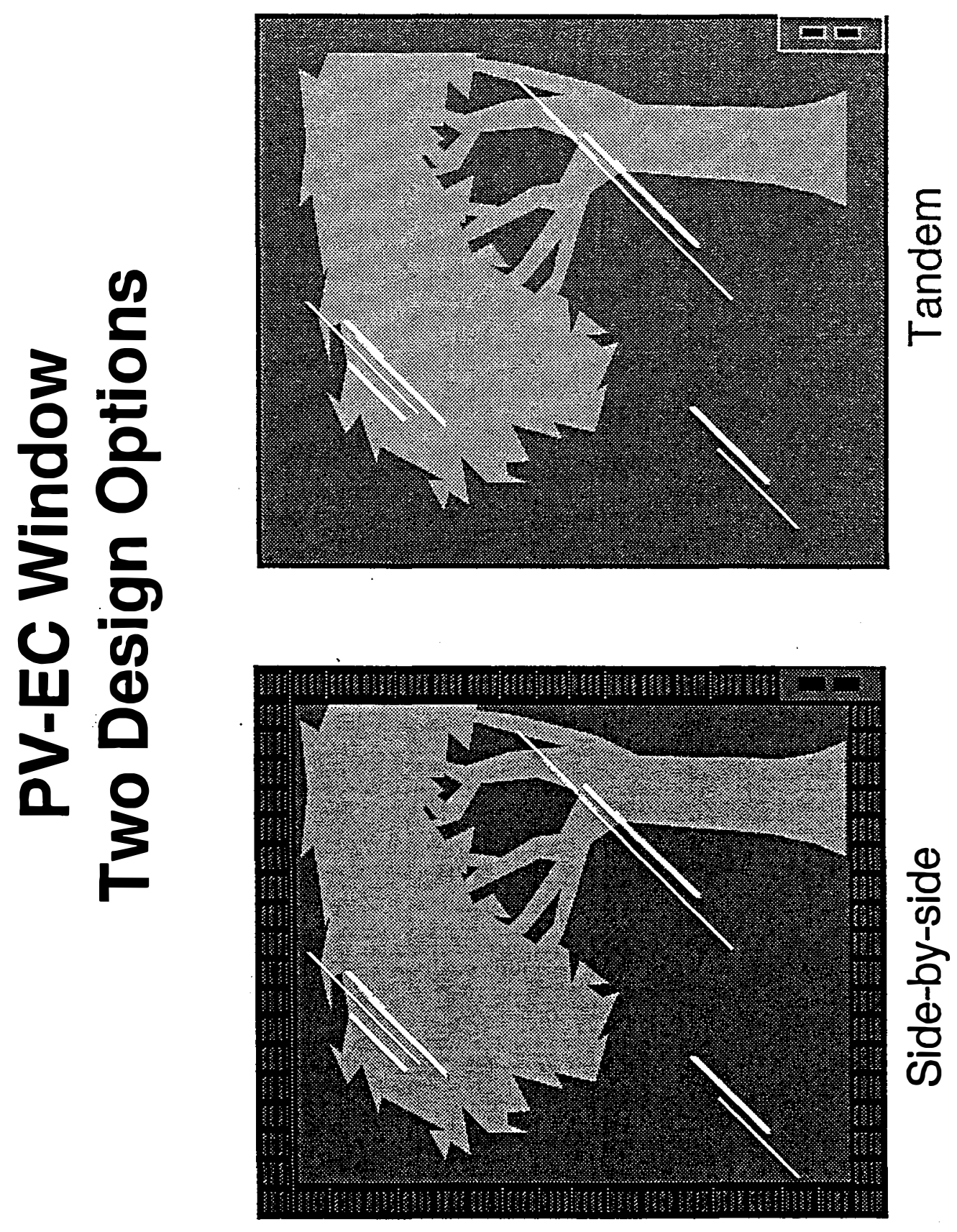




\section{Block Diagram of a PV-EC Window}

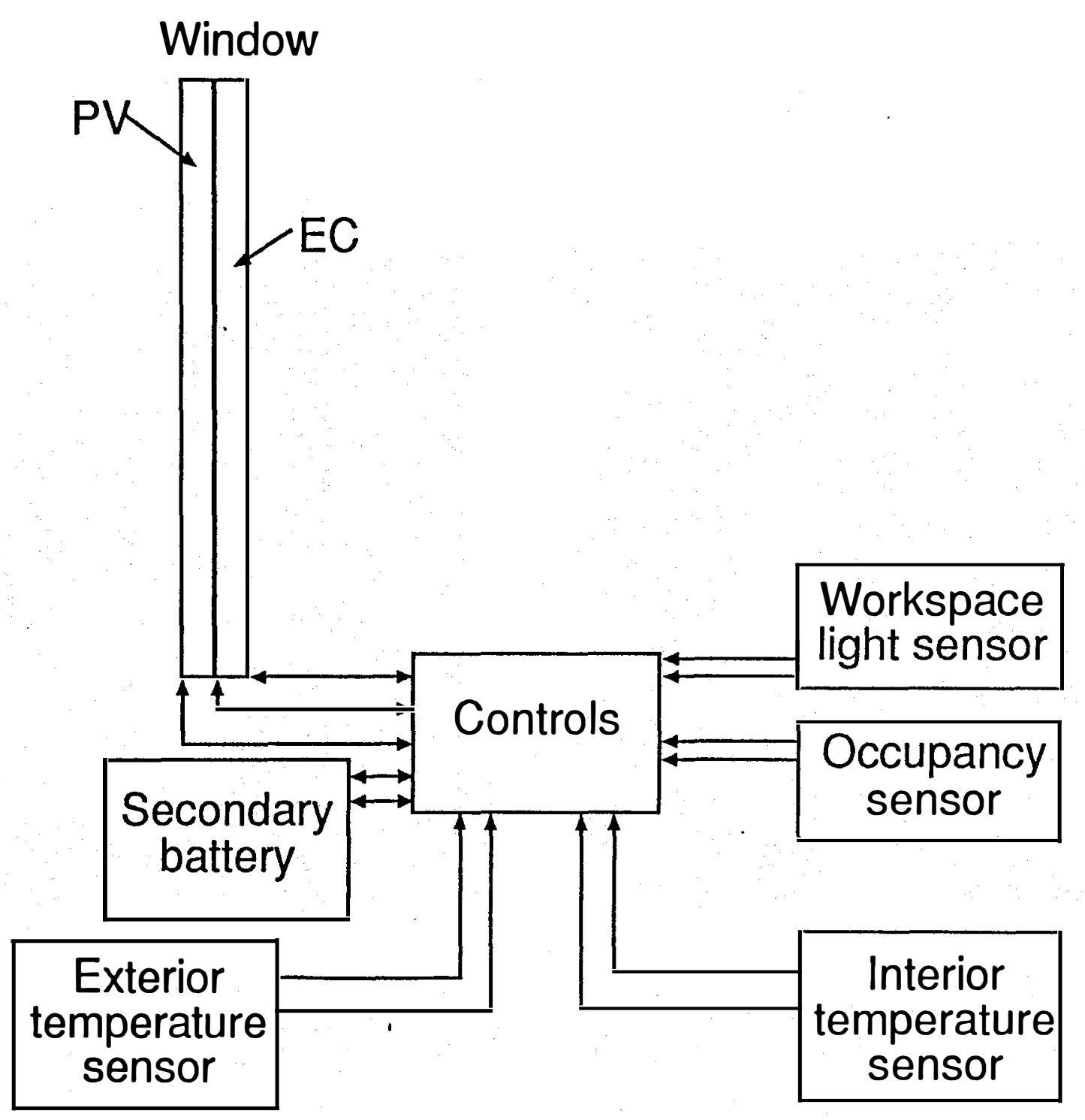




\section{PV-EC Window Heat Gain}

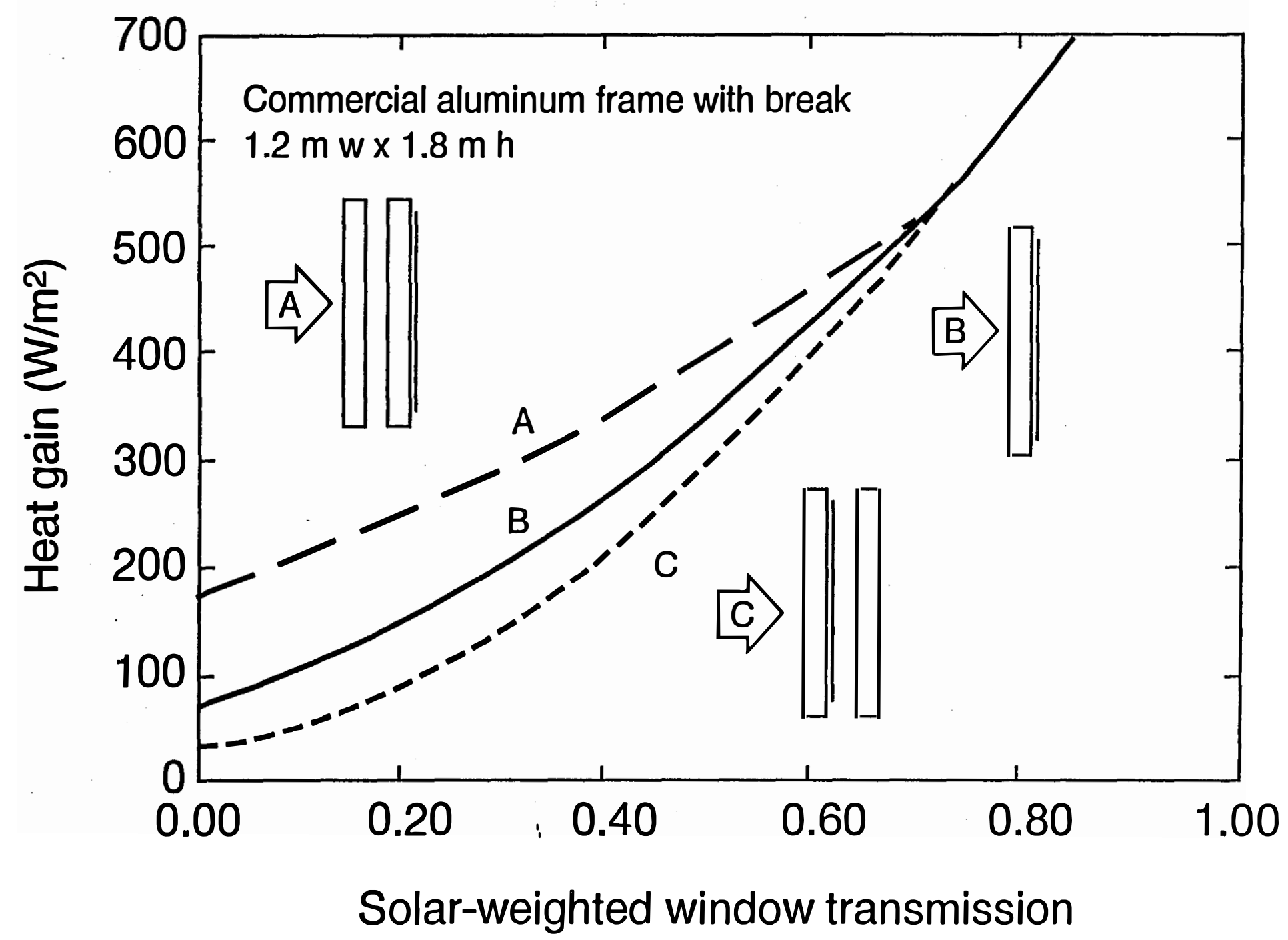




\section{PV-EC Window Heat Gain}

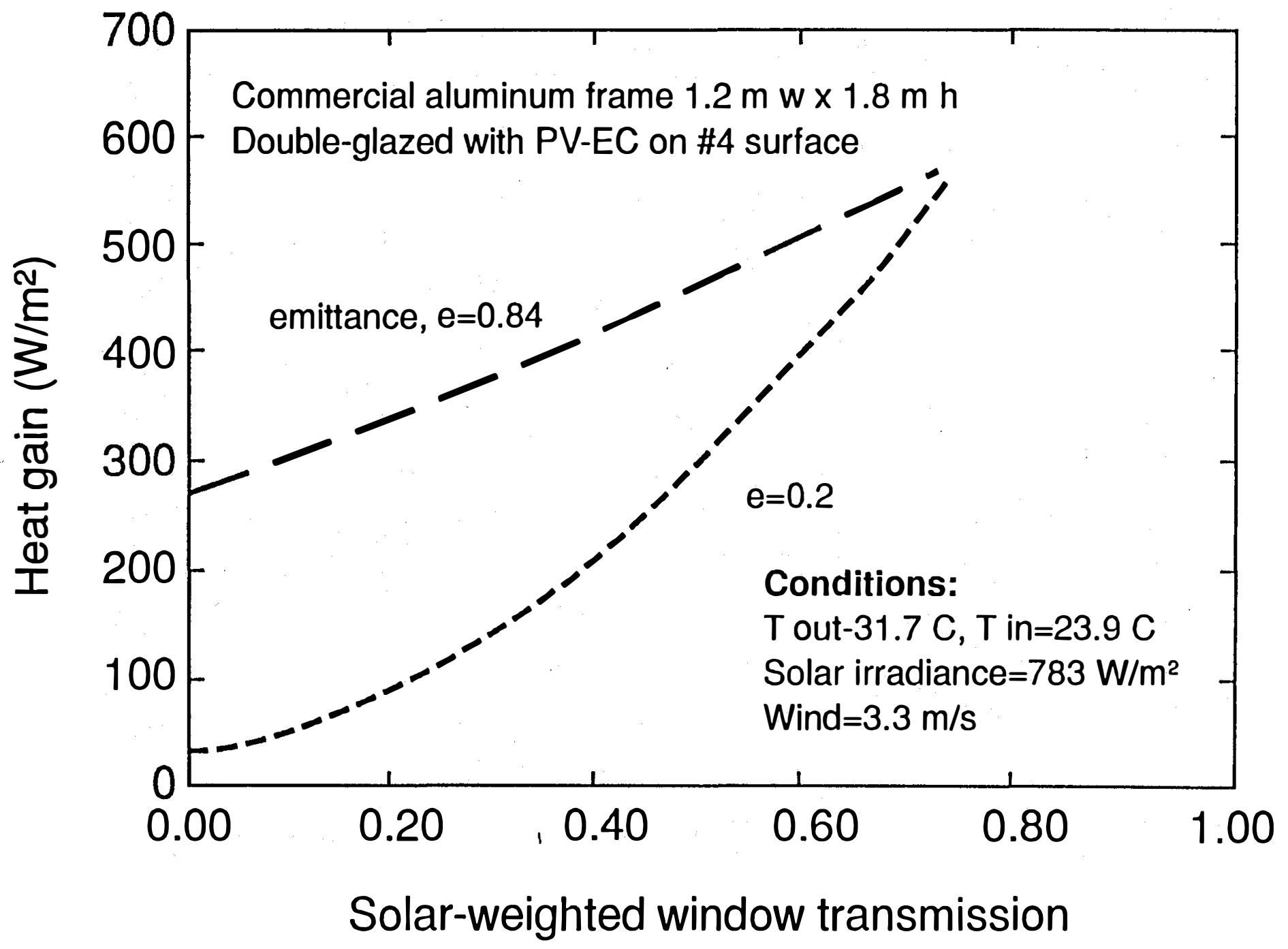



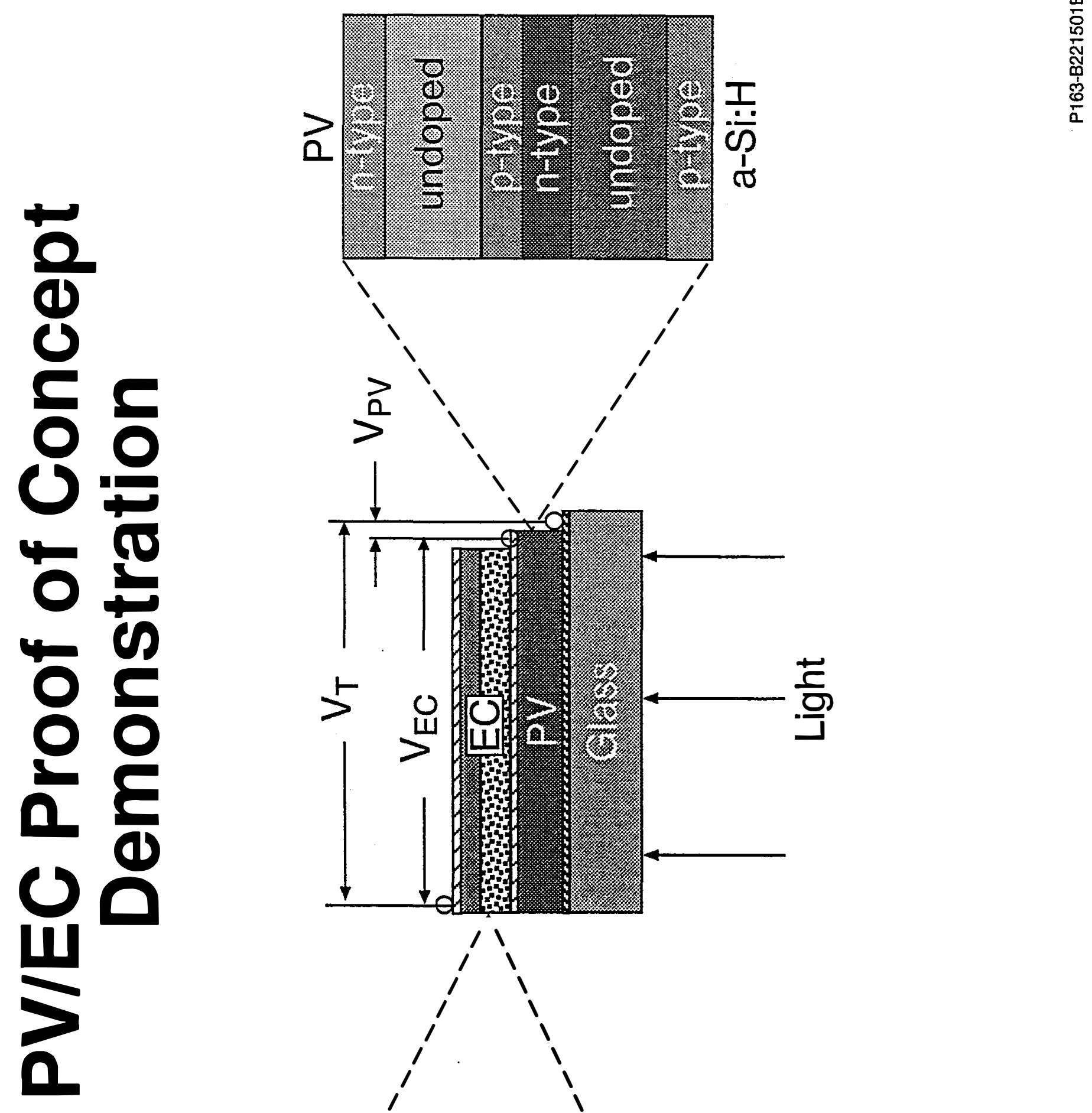

高 a 


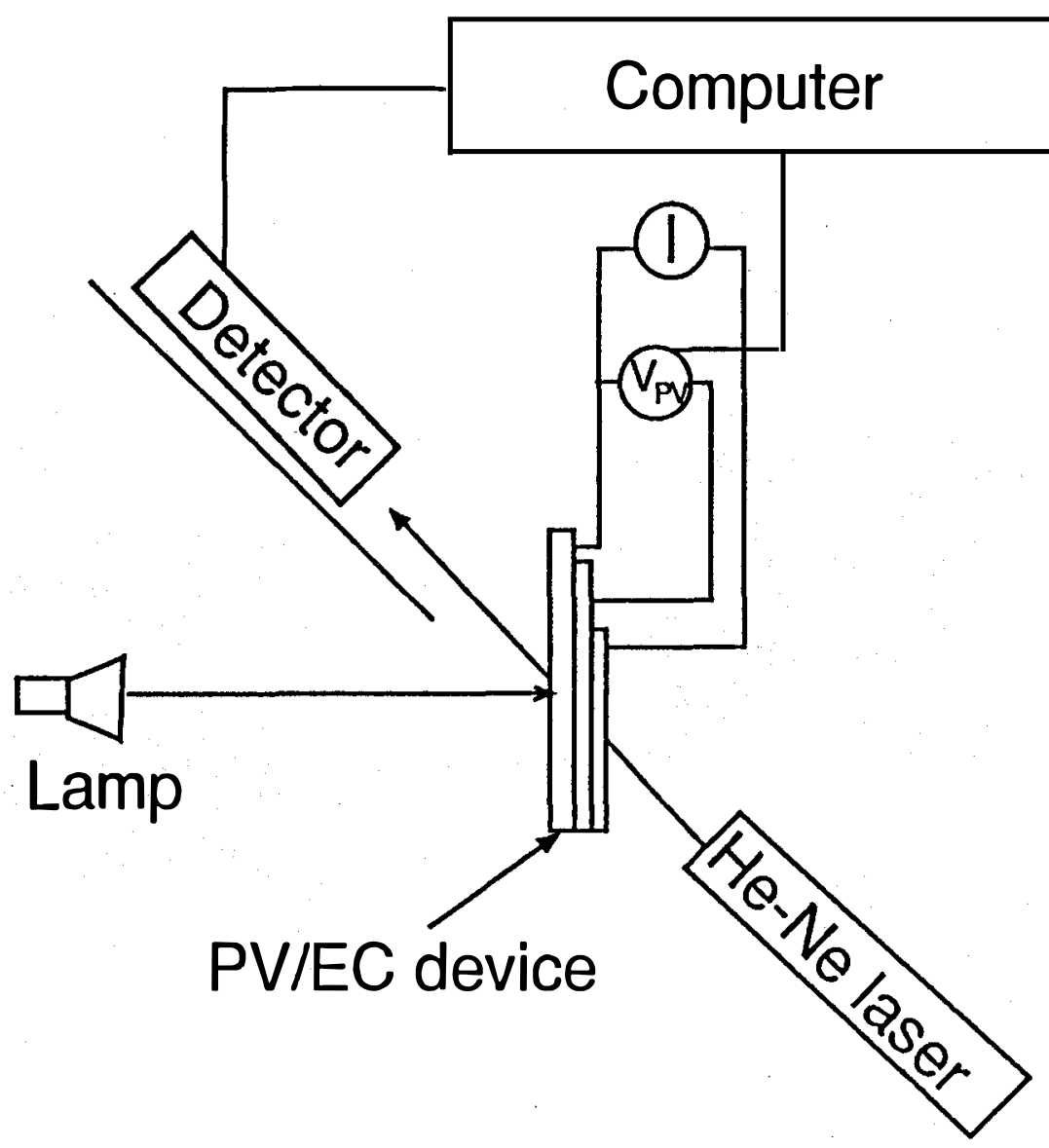

Schematic

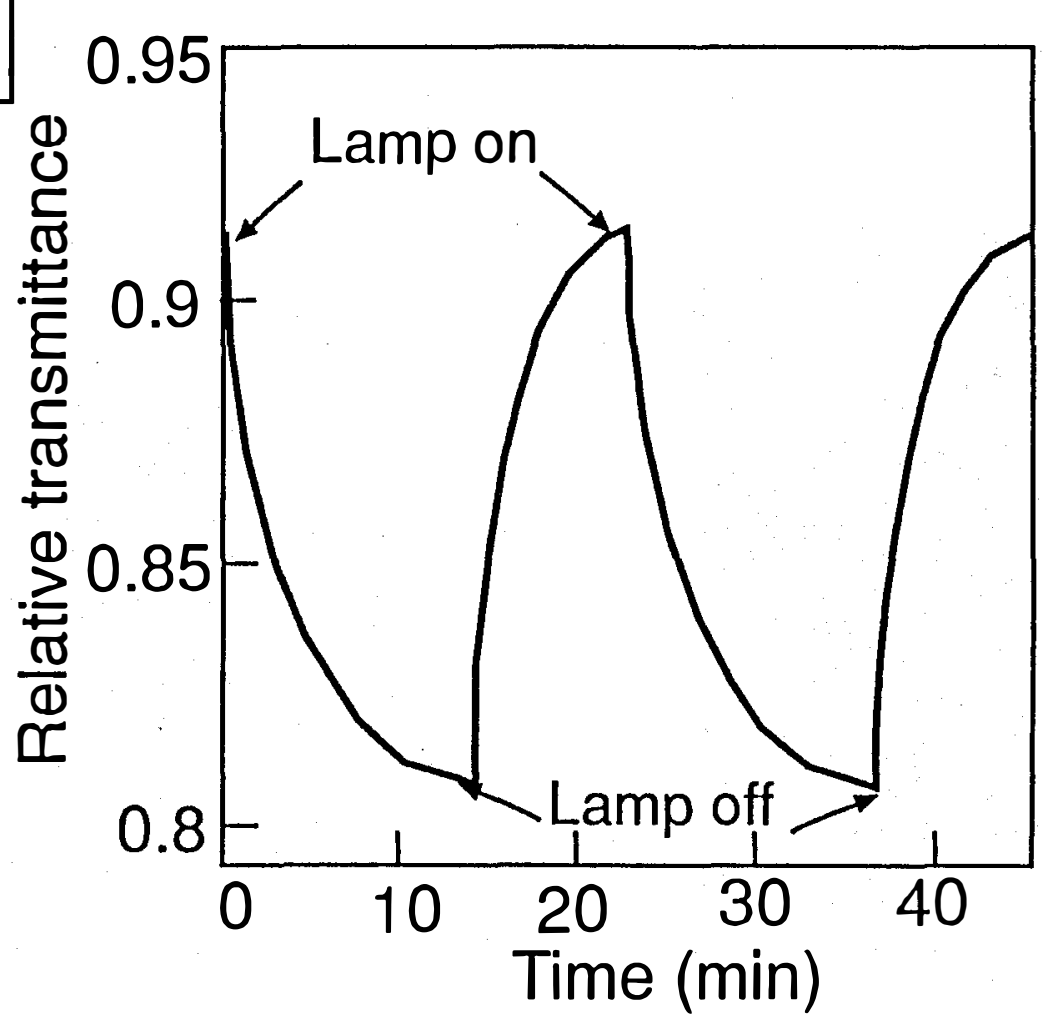

Measured transmittance 


\section{Solar Generated PV Current Density}

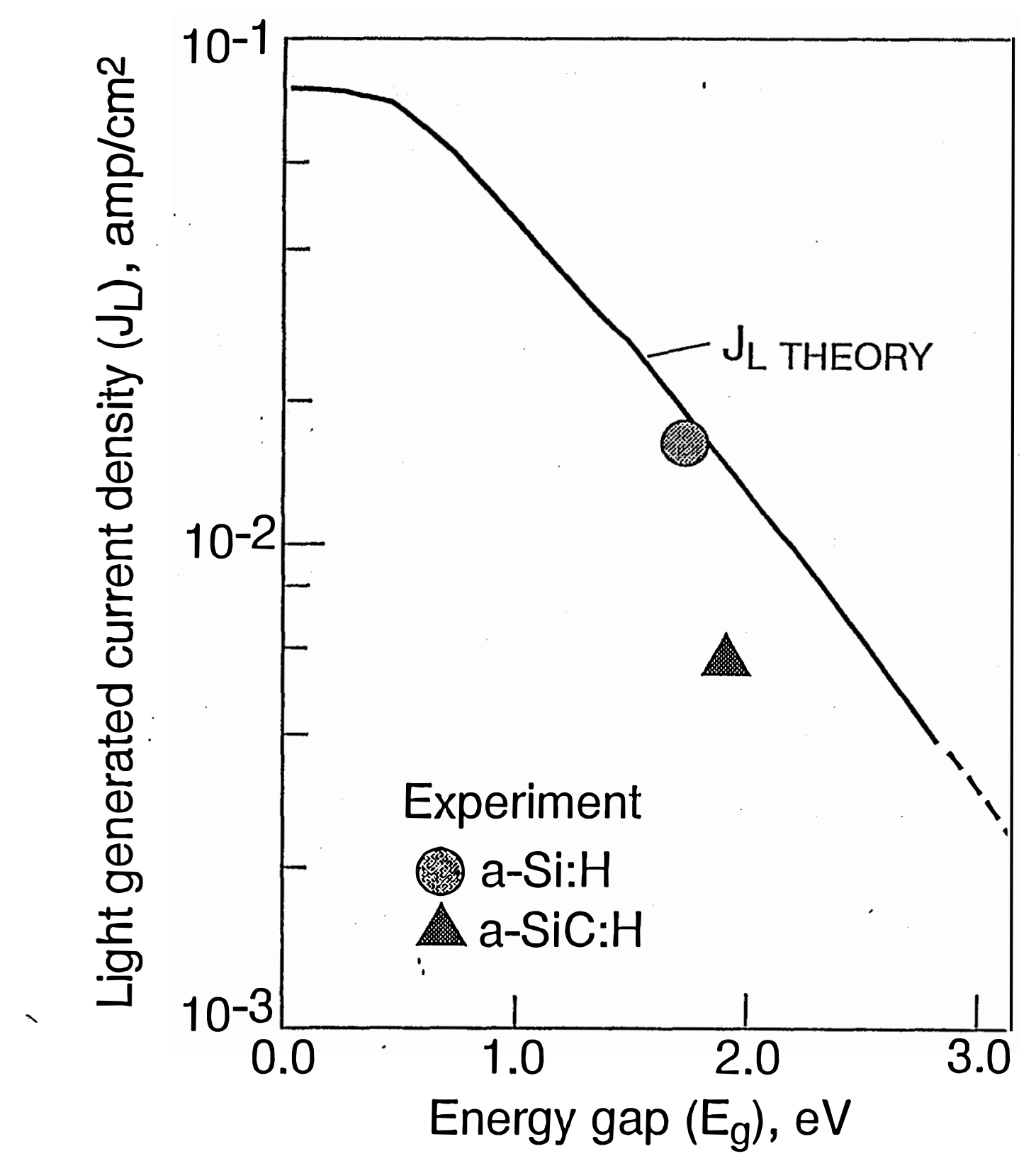




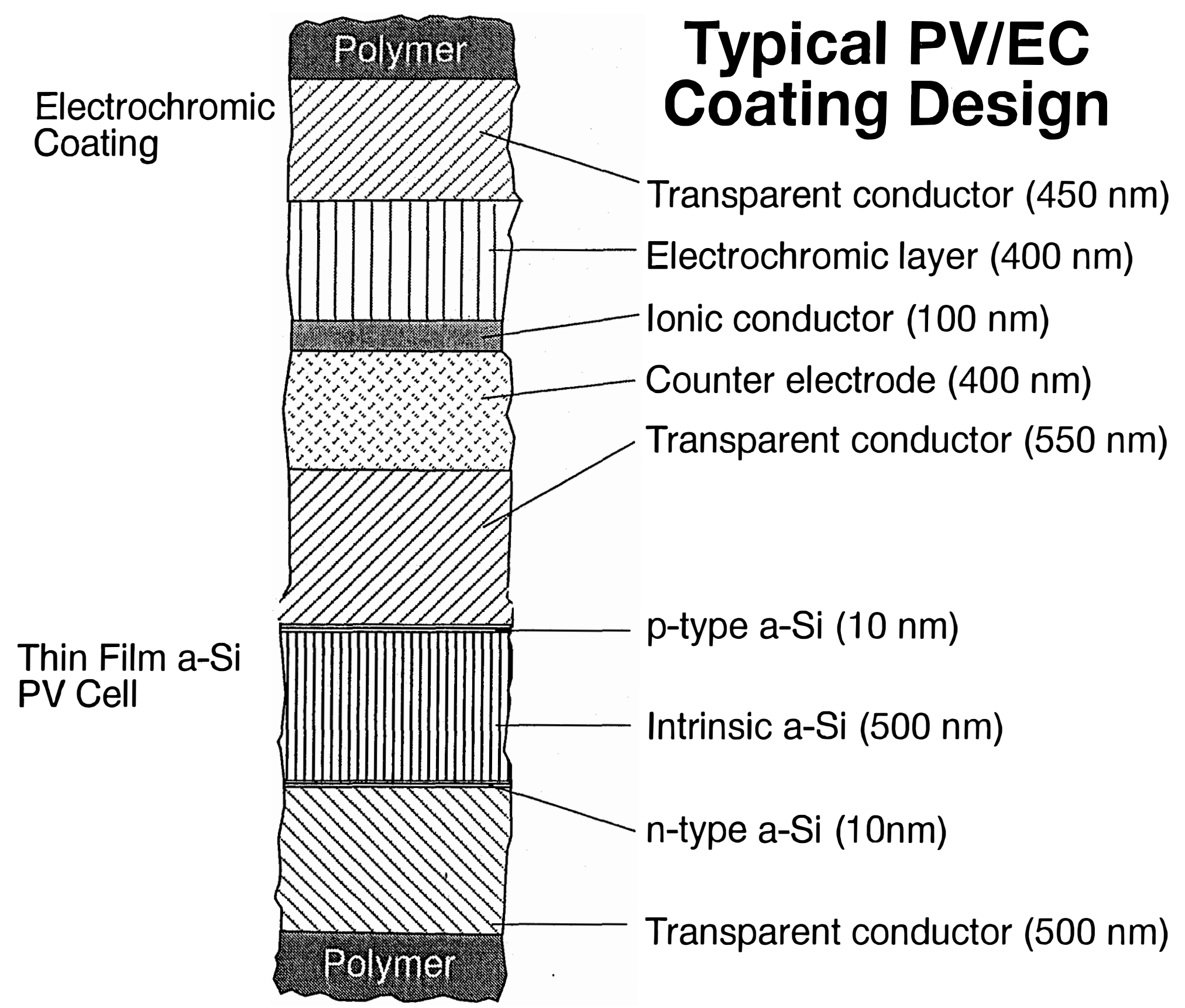

